\title{
PKM Pembinaan Santriwati dalam Meningkatkan Pemahaman Keluarga Sakinah melalui Majelis Taklim di Pesantren Zainul Bahar
}

\author{
Zainul Muin Husni ${ }^{1 *}$, Emilia Rosa ${ }^{2}$, Lilik Handayani ${ }^{3}$
}

Universitas Nurul Jadid, Paiton ${ }^{123}$

Submission: $28 / 12 / 2021 \quad$ Received: $31 / 12 / 2021 \quad$ Published: $31 / 12 / 2021$

Katakunci:

Pesantren, Keluarga Sakinah, Majelis Taklim

\begin{abstract}
Abstrak. Pesantren merupakan tempat untuk meningkatkan dan mengembangkan pemahaman tentang ilmu agama Islam. Salah satu tugas pesantren adalah mendampingi santri agar mampu berperilaku sesuai dengan nilai-nilai dan ajaran ahlus sunnah wal jamaah. Upaya pendampingan tersebut salah satunya diwujudkan dengan melakukan pembinaan kepada santri guna meningkatkan pemahaman keluarga sakinah. Adanya pembinaan ini dimaksudkan untuk menjembatani keinginan sebagian besar santri untuk menikah setelah lulus dari pesantren dan pengetahuan mereka yang masih minim mengenai perkawinan. Pembinaan ini dilakukan dengan pola demokratis dengan pendekatan partisipatif, di mana pembina bersikap terbuka terhadap segala pendapat yang dikemukakan dan didiskusikan secara bersama-sama. Hasil dari pembinaan ini adalah bahwa untuk mewujudkan keluarga yang sakinah, maka seorang istri harus mengamalkan beberapa ajaran yang tertuang dalam kitab alMar'atu as-Sholehah antara lain 1). Mengkomunikasikan setiap persoalan yang muncul dengan suami, 2). Tidak boleh mencela setiap pemberian suami, 3). Tidak membanding-bandingkan suaminya dengan orang lain, 4). Tidak bersikap boros dan/atau terlalu pelit, 5). Tidak berhutang kecuali dharurat, dan sebagainya.
\end{abstract}

\section{Pendahuluan}

Kesehatan reproduksi merupakan suatu kondisi atau keadaan sehat secara menyeluruh baik kesejahteraan fisik, mental dan sosial yang utuh dalam segala hal yang berkaitan dengan fungsi, peran dan proses reproduksi yang dimiliki oleh remaja (Bayang, 2016).

Pada prinsipnya setiap manusia di samping memiliki sisi individual, juga memiliki sisi sosial yang cukup kuat dalam dirinya, di mana ia dengan segenap keterbatasannya selalu membutuhkan orang lain demi keberlangsungan hidupnya. Hubungan sosial antara manusia yang satu dengan yang lainnya tersebut secara umum ada yang hanya bersifat basa-basi, tidak serius dan mendalam, ada pula yang sifatnya legal-formal, seperti hubungan kerjasama dalam bisnis, kontrak kerja, termasuk juga hubungan perkawinan antara lakilaki dan perempuan. Bahkan lebih dari itu, dalam Islam, perkawinan 
merupakan suatu peristiwa yang luhur, sakral dan bernilai ibadah di sisi Allah SWT (Wibisana, 2016).

Secara fiqih, hukum asal suatu perkawinan adalah mubah, dan dapat berubah menjadi wajib, sunah, makruh dan/atau bahkan haram tergantung situasi dan motivasi dilakukannya perkawinan tersebut. Maknanya, jika perkawinan dilihat dari hukum asalnya, setiap orang diperkenankan dan dibolehkan untuk melangsungkan suatu perkawinan kapanpun dan dengan siapapun, asalkan sesuai dengan ketentuan syarat dan rukunnya. Proses perkawinan baru akan menjadi masalah serius manakala perkawinan dilakukan oleh mereka yang masih berusia di bawah umur, hal ini karena peristiwa tersebut pasti akan memicu perhatian dan kontroversi di tengahtengah masyarakat, baik dalam skala nasional maupun internasional (Inayati, 2015).

Berdasarkan hasil survey kerjasama antara United Nations Children's (UNICEF), BPS, dan Bappenas yang didukung oleh Pusat Kajian dan Advokasi Perlindungan dan Kualitas Hidup Anak Universitas Indonesia (PUSKAPA) dan dipublikasikan pada Januari 2020 dinyatakan bahwa pada tahun 2018, 1 dari 9 anak perempuan di Indonesia dalam usia 20-24 tahun menikah sebelum usia 18 tahun, atau lazim disebut dengan perkawinan anak (Hakiki \& dkk, 2020). Hal ini juga diperkuat oleh hasil penelitian Badan Kependudukan dan Keluarga Berencana Nasional (BKKBN) yang menyatakan bahwa di perkotaan usia perempuan pertama menikah ada dikisaran 16-19 tahun, sementara di pedesaan berkisar 13-18 tahun. Hal ini disebabkan karena rendahnya tingkat pendidikan masyarakat sehingga sulit memperoleh pekerjaan yang layak, maka orang tua lebih memilih menikahkan anaknya dari pada menambah beban biaya hidup (Qibtiyah, 2014).

Meski berdasarkan Pasal 7 ayat 1 UU Perkawinan perempuan diizinkan kawin jika telah mencapai usia 16 tahun, sementara pria telah mencapai usia 19 tahun, namun berdasarkan Pasal 1 ayat 1 UU Perlindungan Anak menyatakan bahwa yang dimaksud anak ialah seseorang yang belum berusia 18 tahun, termasuk anak yang masih dalam kandungan. Jadi secara yuridis UU perkawinan selain melegalkan perkawinan anak (Djamilah \& Kartikawati, 2014), juga bertentangan dengan semangat UU Perlindungan Anak, namun sejak UU Perkawinan diubah dengan UU No 16 Tahun 2019 pertentangan 
tersebut dapat diredam. Karena semangat UU No 16 Tahun 2019 tersebut sesuai dengan spirit UU Perlindungan Anak.

Kendati hukum memberikan batasan usia perkawinan terhadap seseorang secara yuridis, namun dalam praktek kehidupan masyarakat, baik di perkotaan terlebih di pedesaaan, perkawinan anak tidak dapat dihindari. Memang perkawinan anak merupakan masalah klasik namun bukan berarti usaha-usaha yang sifatnya preventif dihentikan, sebab seiring perkembangan zaman, faktor penyebab perkawinan anak juga selalu dinamis dan berkembang. Masalah ini pun juga banyak terjadi di Bondowoso, khususnya di wilayah Wringin.

Berdasarkan data dari Badan Pusat Statistik (BPS) Kab. Bondowoso bahwa wilayah Wringin merupakan wilayah dengan keberadaan pondok pesantren terbanyak se kabupaten Bondowoso, yakni terdapat 20 lembaga pondok pesantren (BPS, 2018). Salah satu diantaranya adalah Pondok Pesantren Zainul Bahar.

Sebagaimana umumnya lembaga pondok pesantren, PP. Zainul Bahar yang berlokasi di Desa Wringin Kec. Wringin, Kab. Bondowoso juga melakukan serangkaian kegiatan pendidikan keagamaan. Kegiatan tersebut berjalan sejak dari pagi hari hingga malam tiba, baik kegiatan yang sifatnya ubudiyah maupun taklimiyah. Kegiatan-kegiatan ubudiyah di lingkungan PP Zainul Bahar terdiri dari pelaksanaan shalat fardlu, shalat sunnah, hingga beragam wiridan, istighasah, shalawatan, dan tahlil yang rutin dilaksanakan sesuai dengan jadwal yang telah ditentukan pihak pesantren. Sementara kegiatan taklimiyah meliputi kajian kitab kuning, pendidikan diniyah ula hingga wustho yang memang menjadi ciri khas pesantren baik yang diampu oleh Majelis Keluarga Pesantren maupun para pengurus dan asatidz di lingkungan PP. Zainul Bahar, pendidikan formal yang terdiri dari Madrasah Tsanawiyah, Madrasah Aliyah, dan Sekolah Menengah Kejuruan juga tidak kalah penting bagi pengembangan IPTEK dalam mendidik santri menjadi manusia yang berakhlaqul karimah, berwawasan keilmuan yang luas, dan mandiri dalam menghadapi tantangan masa depan (I. Marzuki, personal communication, 2021).

Dengan jumlah santri yang cukup banyak, biaya pendidikan yang murah, fasilitas pendidikan yang memadai, dan lulusan/alumni yang telah terbukti memiliki banyak peran penting dalam kehidupan masyarakat, tidak heran jika 
PP Zainul Bahar menjadi salah satu pesantren yang banyak diminati oleh masyarakat sekitar untuk dijadikan tempat pendidikan bagi anak-anak mereka. Hingga saat ini, pesantren ini telah memiliki kurang lebih 500-an santri baik yang bermukim maupun non-mukim, yang berasal dari daerah Bondowoso, Jember, dan Situbondo, dengan mayoritas santri berasal dari pelosok desa di sekitar Kab. Bondowoso.

Banyaknya santri yang secara georgafis berada di pelosok dan kaki pegunungan di sekitar Kab. Bondowoso disinyalir menjadi salah satu faktor yang mempengaruhi pola pikir sebagian santri untuk melangsungkan perkawinan di usia muda. Di samping karena faktor yang lain, seperti dorongan orang tua, keterbatasan ekonomi, perjodohan sejak masih usia belia atau bahkan masih di dalam kandungan, tingkat pendidikan yang rendah, sangat kuatnya hubungan emosional seseorang dengan calon pasangannya, maupun kehamilan di luar perkawinan, dan sebagainya.

Oleh karena itu, pendidikan yang berhubungan dengan pernikahan menjadi sangat penting, terutama bagi santri yang bermukim di asrama pesantren. Meskipun santri dalam aktivitas kesehariannya selalu bergelut dengan kajian-kajian keagamaan, namun uraian atau penjelasan yang secara khusus berbicara tentang perkawinan sangat terbatas waktunya. Di samping memang karena padatnya kegiatan/program di lingkungan pesantren yang mengaji berbagai bidang ilmu, seperti ilmu alat, ushul fiqih, fiqih, akhlak, tasawuf, al-Qur'an, dan sebagainya. Karena memang santri tidak dicetak untuk mendalami secara khusus bidang ilmu tertentu. Dari sinilah kemudian menjadi sangat urgen untuk diselenggarakannya pembinaan santri melalui majelis taklim dengan mengkaji kitab al-mar'atus sholihah yang disandingkan dengan hukum perkawinan di Indonesia guna meningkatkan pemahaman santri tentang keluarga sakinah sekaligus sebagai upaya preventif menghindari terjadinya pernikahan anak.

\section{Metode}

Pola pembinaan yang digunakan ialah pola pembinaan yang demokratis dengan pendekatan partisipatif, di mana pendidik bersikap terbuka terhadap tuntutan dan pendapat yang dikemukakan seseorang, kemudian mendiskusikan hal tersebut secara bersama-sama. Pola ini ditandai dengan 
sikap menerima, responsif, berorientasi pada kebutuhan anak yang disertai dengan tuntutan, kontrol, dan pembatasan, sehingga memberi keleluasaan pada anak untuk menyampaikan segala persoalan yang dialaminya tanpa rasa takut (Hamang \& Sumadin, 2015). Pembinaan ini berlangsung selama 2 bulan, yakni dimulai sejak minggu pertama bulan Februari 2021-akhir bulan Maret 2021, dan dilaksanakan satu minggu sekali yakni setiap hari Jum'at pagi, karena di hari tersebut kegiatan pesantren kosong, sehingga diharapkan tujuan dari pembinaan ini dapat berjalan maksimal.

Pola pembinaan demokratis yang digunakan dalam pembinaan santriwati dalam meningkatkan pemahaman keluarga sakinah di PP. Zainul Bahar ini memiliki beberapa tahapan, antara lain;

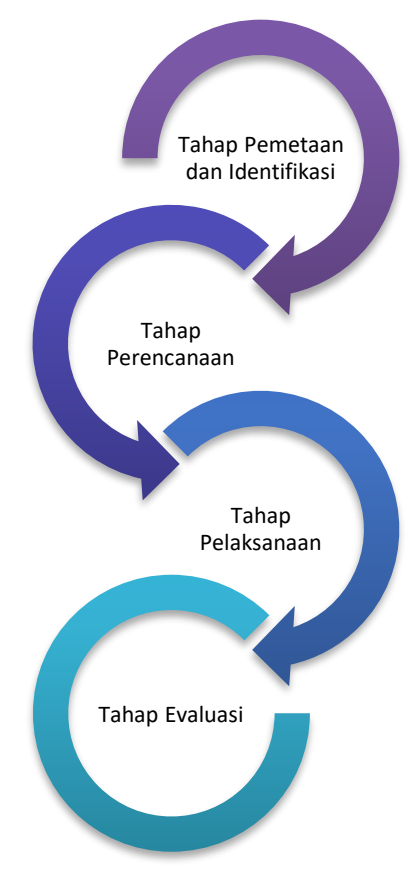

a. Tahap Pemetaan dan Identifikasi Permasalahan; tahap ini merupakan langkah awal bagi penulis guna memahami segala persoalan yang dihadapi oleh seluruh peserta binaan. Dengan demikian, tahap ini merupakan tahap kunci bagi penulis untuk mengetahui dan memahami segala persoalan, khususnya yang terkait dengan faktor penyebab maraknya terjadinya perkawinan anak.

b. Tahap Perencanaan Pembinaan; tahap kedua ini merupakan tahap untuk menyusun strategi kegiatan selama proses pembinaan guna menyelesaikan problem atau permasalahan yang terjadi. Langkah 
penyusunan strategi pembinaan ini dilakukan dengan melibatkan seluruh peserta binaan, guna mensuksekan kegiatan pembinaan dimaksud.

c. Tahap Pelaksanaan; setelah rencana tersusun dengan baik, maka pada tahap ini semua rencana tersebut diimplementasikan secara bersama, yakni dengan mengkaji kitab yang telah disepakati pada tahap perencanaan ditambah dengan pemaparan peraturan perundangundangan yang berlaku di Indonesia. Tahap ini dilaksanakan secara partisipatif dan terbuka, guna memberi pemahaman lebih mendalam mengenai keluarga sakinah.

d. Tahap Evaluasi; tahap ini merupakan sarana untuk memperhatikan, mengukur, dan menganalisis secara seksama tingkat keberhasilan, ketercapaian, kelemahan, dan kekurangan yang terjadi dalam proses pembinaan, selain juga memberi catatan penting yang terkait dengan hal-hal yang menjadi faktor penghambat dan pendukung suksesnya pembinaan dimaksud.

\section{Hasil dan Pembahasan}

Sebagaimana telah disebutkan pada bagian terdahulu bahwa secara teknis pembinaan ini meliputi 4 (empat) langkah utama, di mana masing-masing bagian saling terkait satu dengan yang lainnya. Langkah atau tahapan awal hingga tahap akhir akan diuraikan secara sistematis dan komprehensif sebagai berikut;

\section{Tahap Pemetaan dan Identifikasi Masalah}

Tim melakukan proses pemetaan sekaligus mengidentifikasi berbagai masalah di lapangan pada tanggal 07 Februari 2021. Sebelum pemetaan dilakukan, berbekal surat tugas dari Lembaga Penerbitan, Penelitian, dan Pengabdian kepada Masyarakat Universitas Nurul Jadid (LP3M UNUJA), Tim terlebih dahulu meminta izin kepada pengurus pesantren Zainul Bahar untuk melakukan kegiatan pembinaan ini, mulai dari menentukan waktu, tanggal kegiatan, hingga sasaran binaan. Rencana awal kegiatan pembinaan ini akan dilaksanakan secara pararel selama kurang lebih 2 minggu, namun karena sulitnya mencari hari dan waktu yang kosong akhirnya Tim dan pengurus pesantren menyepakati pelaksanaan kegiatan ini akan diselenggarakan setiap 
hari Jum'at pukul 06.00-07.00 WIB selama 4 kali pertemuan, dengan tetap mematuhi protokol kesehatan.

Selama proses pemetaan dan identifikasi masalah dilakukan, Tim berhasil menemukan beberapa persoalan atau masalah yang dihadapi para peserta binaan, antara lain bahwa faktor ekonomi dan kultur nikah muda menjadi faktor utama terjadinya pernikahan dini. Budaya yang berkembang di tengah masyarakat seperti memberi stigma negatif terhadap perempuan yang telah sangat matang dari sisi usia namun belum menikah dengan sebutan perawan tua, disinyalir juga menjadi salah satu faktor pendorong masih maraknya perkawinan anak. Informasi ini diperoleh Tim dengan wawancara semi terstruktur kepada sejumlah peserta binaan, terutama santriwati di lingkungan PP. Zainul Bahar yang akan melangsungkan perkawinannya beberapa bulan ke depan. Selain itu, Tim juga melakukan penggalian datadata lainnya yang dianggap penting dan terkait dengan pembinaan ini.

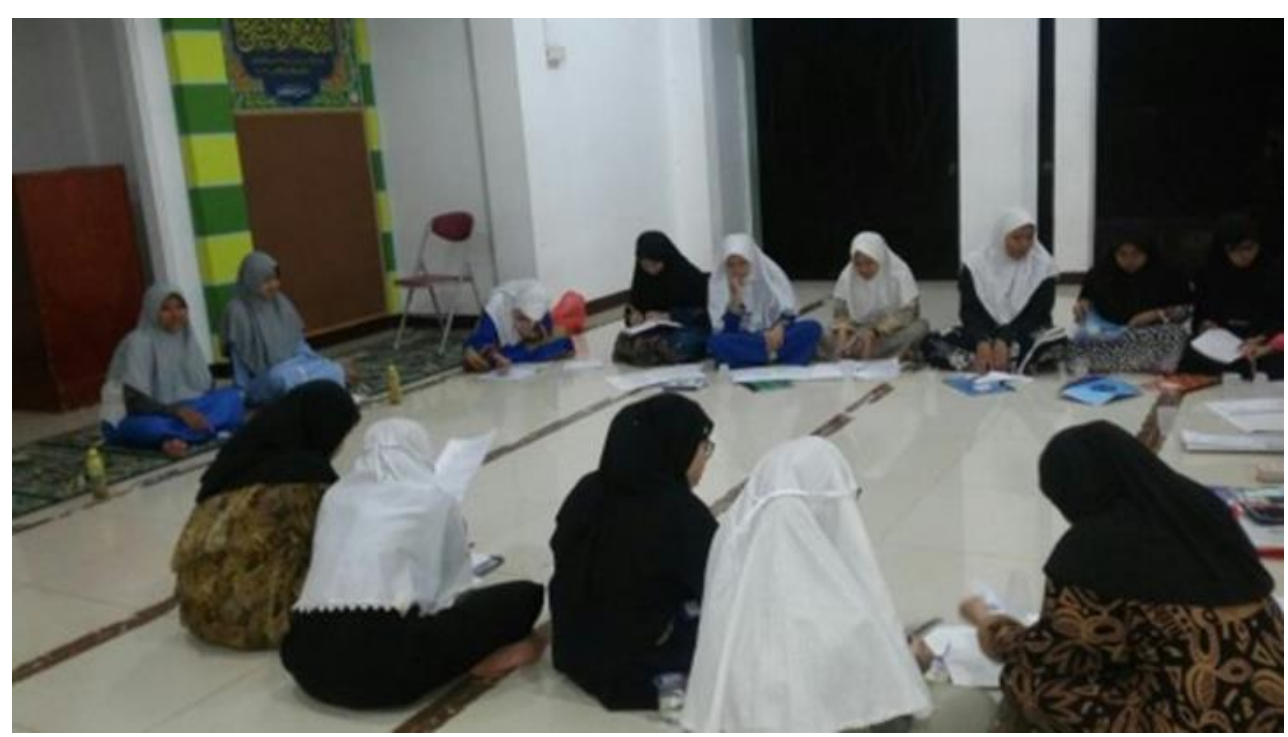

Gambar 1: Rapat Persiapan

\section{Tahap Perencanaan Pembinaan}

Setelah proses pemetaan dan pengidentifikasian masalah selesai, maka Tim melakukan focus group discussion (FGD) guna menentukan tindak lanjut berikutnya, yakni merencanakan format kegiatan pembinaan. Hal ini dimulai dengan menentukan tema yang sesuai dengan kondisi di lapangan, waktu pelaksanaan kegiatan, penanggungjawab kegiatan pembinaan, hingga kitab 
wajib yang akan dijadikan rujukan primer guna memecahkan berbagai persoalan di lapangan.

Pada tahap ini, Tim menyepakati tema penting kegiatan pembinaan ini adalah Upaya meningkatkan Pemahaman Santriwati tentang Keluarga Sakinah melalui Majelis Ta'lim. Waktu pelaksanaannya sesuai dengan keputusan bersama antara Tim dengan pengurus pesantren ialah empat (4) kali pertemuan setiap hari Jum'at pagi yang dimulai pada pukul 06.00-07.00 WIB dan akan diselenggarakan untuk pertemuan pertamanya ialah pada tanggal 05 Maret 2021. Jadi kegiatan ini nantinya jika tidak ada halangan atau hambatan akan berakhir pada 26 Maret 2021. Selain itu, Tim sepenuhnya menyepakati $\mathrm{KH}$. Zainul Mu'ien Husni sebagai penanggung jawab utama terselenggaranya kegiatan pembinaan ini, dengan pertimbangan selain karena beliau tokoh agama yang disegani dan dihormati oleh masyarakat, juga kapasitas beliau yang memang ahli di bidang ilmu fiqih dan hukum Islam, baik hukum Islam klasik maupun hukum Islam kontemporer.

Dalam proses penentuan sumber rujukan utama (primer) kegiatan pembinaan ini, sebenarnya ada banyak sekali kitab yang ditawarkan dalam forum FGD tersebut, mulai dari kitab Qurratul Uyun, Fathul Izar, Uqudul Lujjain, Hadiyatul 'Arus, Al-Fawaid fi An-Nikah, Masail An-Nikah, dan lain sebagainya, termasuk juga kitab Al-Mar'ah Ash-Sholihah. Akhirnya disepakati kitab yang akan dijadikan sebagai rujukan selama proses pembinaan ialah kitab Al-Mar'ah Ash-Sholihah, dipilihkan kitab tersebut tidak lepas dari beberapa pertimbangan berikut;

a. Kitab tersebut memuat cukup komprehensif mengenai akhlak seorang perempuan

b. Kitab tersebut juga berisi tata cara atau bagaimana seorang perempuan bersikap, terutama saat menjalani kehidupan rumah tangga

c. Termasuk kitab yang mudah dipelajari, dipahami dan dipraktekkan bagi seorang perempuan

d. Kitab tersebut cukup ringkas, terdiri dari 64 halaman dan 16 bab. 

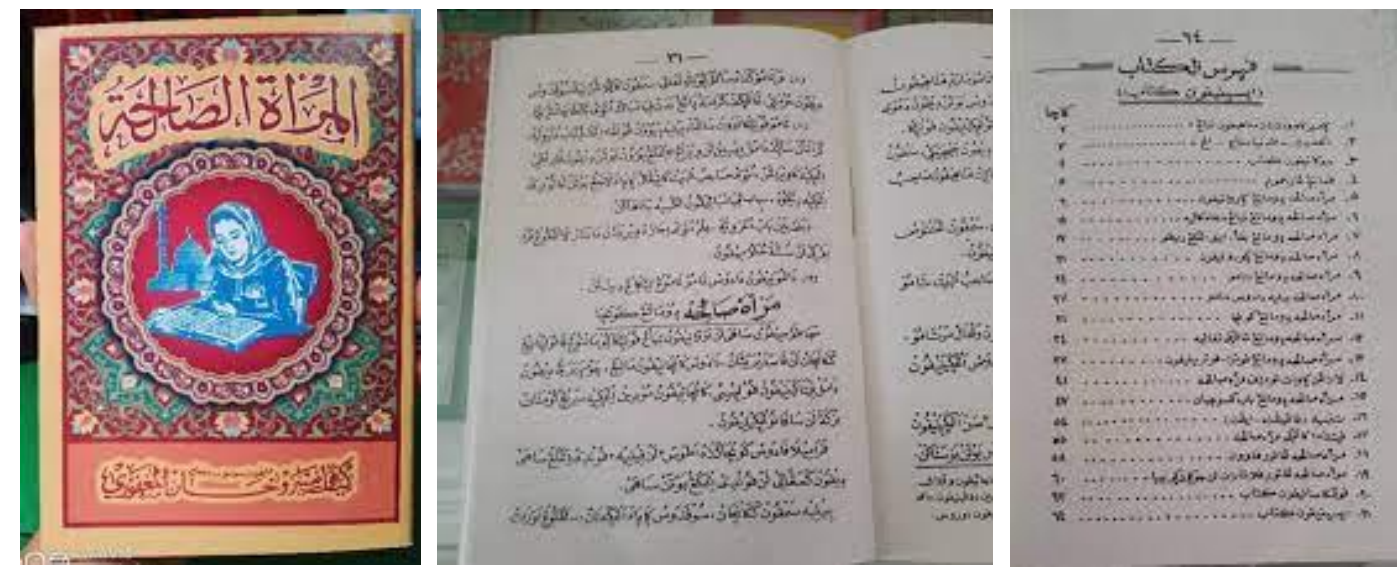

Gambar 2: Kitab Al-Mar'atus Sholihah

Perlu diketahui bahwa tidak semua bab yang ada dalam kitab tersebut dipelajari, hanya bab-bab tertentu saja yang memiliki korelasi dan relevansi dengan kegiatan pembinaan dikaji secara mendalam, agar para peserta dapat memahami dengan baik misalnya bagaimana bersikap, bergaul, dan berakhlak saat berada di lingkungan keluarga, kerabat, teman, maupun masyarkat.

Selain itu, tidak lupa disela-sela penyampaian kajian kitab, juga disisipkan uraian/argumentasi yuridis yang dirujuk langsung dari UU Perkawinan, KHI, UU Perlindungan Anak, maupun peraturan-peraturan lainnya yang relevan. $\mathrm{Hal}$ ini bertujuan selain untuk semakin mematangkan hakikat sebuah perkawinan yang kelak akan dijalani peserta binaan, juga untuk mencegah terjadinya perkawinan anak.

\section{Tahap Pelaksanaan Kegiatan}

Pada tahap ini, seluruh perencanaan yang telah disiapkan sebelumnya dengan baik akan diimplementasikan kepada seluruh peserta binaan. Pada pertemuan pertama, majelis taklim ini dipimpin langsung oleh $\mathrm{KH}$. Zainul Mu'iem Husni dan dihadiri oleh kurang lebih 20 santriwati yang bermukim di Pesantren Zainul Bahar. Pada kesempatan ini, pembina mengawali dengan penjelasan tentang asal-usul lahirnya kitab Al-Mar'ah Ash-Sholihah. Bahwa kitab tersebut bukan merupakan karangan dari ulama'-ulama' timur tengah, 
melainkan ditulis oleh salah satu ulama' karismatik Indonesia yang bernama $\mathrm{KH}$. Masruhan Ichsan Al-Hafidz atau lebih familiar dikenal dengan sebutan $\mathrm{KH}$. Masruhan Al-Maghfuri, karena selain beliau hafal al-Qur'an juga menjadi pendiri sekaligus pengasuh di Pondok Pesantren Putra Putri Al-Maghfuri yang terletak di Desa Bandungrejo, Kecamatan Mranggen, Kabupaten Demak, Jawa Tengah. Beliau wafat pada tanggal 24 Juni 1982 M/2 Ramadhan 1402 H, karena menderita suatu penyakit selama 5 tahun (Munadiroh, 2018).

Lahirnya kitab Al-Mar'ah Ash-Sholihah tidak lepas dari kekhawatiran beliau akan kondisi pendidikan akhlak dan berbagai permasalahan bagi kaum perempuan, mengingat banyaknya perempuan yang ketika menghadapi persoalan rumah tangga tidak selalu diselesaikan di internal keluarganya melainkan dibicarakan diruang-ruang publik, membuka aib keluarga dan sebagainya. Pun demikian, banyak pula perempuan yang belum memahami berbagai permasalahan pada dirinya, seperti belum memahami masalah nifas, haid, dan lain-lainnya. Untuk itulah penting bagi kaum perempuan membaca, mengkaji, dan memahami kitab Al-Mar'ah Ash-Sholihah ini.

Selain itu, kesempatan pertama ini juga dijelaskan beberapa poin yang terdapat dalam kitab Al-Mar'ah Ash-Sholihah antara lain;

a. Saat terjadi persoalan keluarga, terlebih dahulu hendaknya dikomunikasikan dengan pasangannya;

b. Ketika ada kepentingan di luar rumah, seorang istri harus memohon izin terlebih dahulu kepada suaminya;

c. Sebaliknya saat suami tidak sedang berada di rumah, maka istri harus menjaga harta dan jiwanya dengan baik;

d. Saat berkomunikasi dengan suaminya harus menggunakan bahasa yang sopan dan lemah lembuh.

e. Ketika suami memberi sesuatu, hendaknya diterima dengan menggunakan kedua tangannya dan menampakkan ekspresi manja.

Pada pertemuan kedua, pembina melanjutkan kajiannya pada poin berikutnya yakni;

a. Tidak boleh mencela pemberian suami, seberapapun murahnya pemberian tersebut;

b. Saat suami hendak pergi atau datang, seorang istri membiasakan bersalaman sambil mencium tangan suaminya; 
c. Usahakan ketika hendak makan dilakukan secara bersama, agar jika salah satu dari keduanya lupa berdoa, yang lain dapat mengingatkan;

d. Tidak boleh membantah suami;

e. Jika suami kedatangan tamu dan si suami sedang di rumah, istri hendaknya segera menyuguhkan jamuan/hidangan yang dimiliki.

Pada pertemuan ketiga, materi kajian yang disampaikan meliputi;

a. Tidak meminta suami membelikan pakaian, melainkan lebih baik menunggu dibelikan oleh suami

b. Tidak menceritakan pangkat, finansial/kekayaan atau apapun kelebihan yang ada pada suami pada orang lain;

c. Tidak membanding-bandingkan suaminya dengan suami orang lain atau sebaliknya mengunggulkan orang lain di depan suaminya;

d. Tidak memerintah atau menyuruh suami melakukan suatu hal yang suaminya tidak berkenan;

e. Tidak bersikap boros dan/atau terlalu pelit

Selanjutnya pada pertemuan terakhir, kajian dilanjutkan dengan penjelasan tentang;

a. Tidak berhutang kecuali sangat terpaksa karena kondisi yang dhoruri dan harus atas seizin suami;

b. Istri tidak memotong pembicaraan suami saat sedang berdiskusi/bermusyawarah dengannya;

c. Istri tidak berpuasa sunnah kecuali atas seizin suaminya

d. Istri seyogyanya bisa membuat masakan yang sesuai dengan situasi dan kondisi dan menjadi kesukaan suami;

e. Seorang istri tidak boleh menolak ketika sang suami menginginkan untuk berkumpul (jimak). 

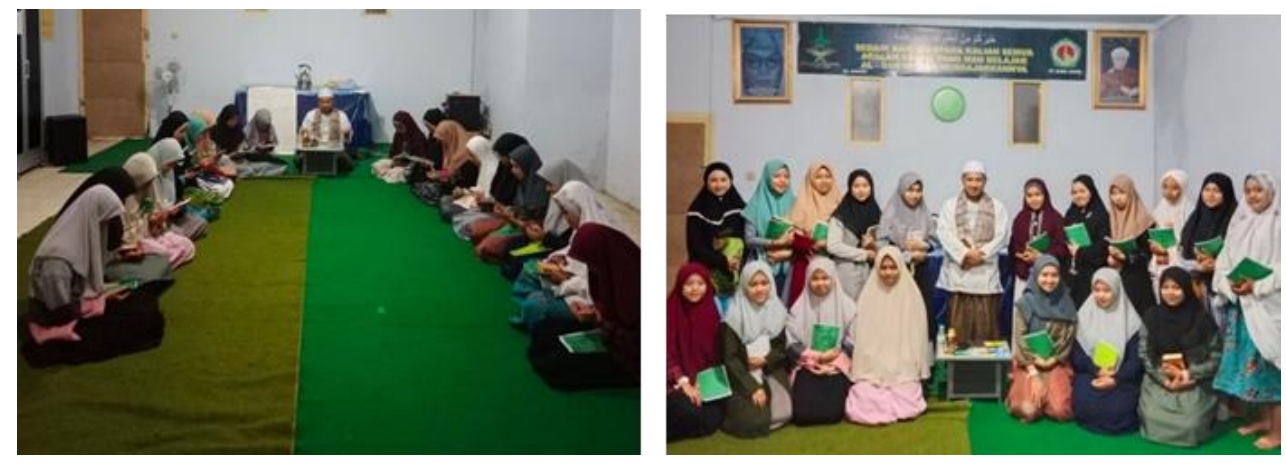

Gambar 3: Pelaksanaan Kegiatan

Selain itu, disela-sela penyampaian kajian kitab, pembina juga menguraikan tentang makna perkawinan berdasarkan hukum positif, bahwa berdasarkan UU Perkawinan, perkawinan bermakna;

"ikatan lahir batin antara seorang pria dengan seorang wanita sebagai suami isteri dengan tujuan membentuk keluarga (rumah tangga) yang bahagia dan kekal berdasarkan Ketuhanan Yang Maha Esa" (Undang-Undang Nomor 1 Tahun 1974 Tentang Perkawinan, 1974).

Dari makna yuridis mengenai perkawinan di atas dapat dipahami bahwa sebuah pernikahan tidak ditujukan hanya untuk sementara waktu, melainkan kekal dan abadi. Untuk bisa mencapai kekekalan dan kelanggenan dalam sebuah perkawinan diperlukan syarat-syarat tertentu, terutama yang berkaitan dengan kesehatan fisik dan mental. Oleh karena itu, pemerintah memberi batasan usia perkawinan baik bagi laki-laki maupun perempuan minimal 19 tahun (Undang-Undang (UU) Tentang Perubahan Atas UndangUndang Nomor 1 Tahun 1974 Tentang Perkawinan, 2019). Namun dalam praktek di tengah masyarakat Indonesia tidak selalu sesuai dengan peraturan pembatasan usia tersebut. Masyarakat lebih banyak taat dan patuh pada pelaksanaan perkawinan hukum adat (Wafiq \& Santoso, 2017). Hal ini pun juga masih marak terjadi di Bondowoso, sebagian masyarakat menikahkan anaknya cukup hanya dengan mendatangkan tokoh agama atau ustad dan mengundang sebagian kecil anggota keluarganya, tanpa melibatkan pegawai pencatat nikah (PPN) dari Kantor Urusan Agama (KUA) setempat. Hal ini karena mayoritas usia calon mempelai masih belum memenuhi ketentuan 
dalam peraturan perundang-undangan perkawinan. Perkawinan semacam ini tentu memiliki resiko yang tinggi, seperti kematian ibu dan bayi. Sebagaimana disampaikan oleh Kepala Dinas Kesehatan Bondowoso, dr. H. Mohammad Imron, bahwa sepanjang tahun 2020, angka kematian Ibu (AKI) dan angka kematian Bayi (AKB) di Bondowoso mengalami peningkatan dari tahun sebelumnya.

Data dari Dinas Kesehatan Bondowoso mencatat pada tahun 2019, kematian ibu berjumlah 14 kasus (129,2/100.000 kelahiran hidup) dan kematian bayi berjumlah 155 kasus (14,3/1000 kelahiran hidup). Sementara pada tahun 2020, jumlah kematian ibu tercatat 19 kasus $(177,4 / 100.000$ kelahiran hidup) dan untuk kematian bayi sebanyak 168 kasus (15,6/1000 kelahiran hidup) (ikilhojatim.com, 2021). Lebih lanjut dikatakan bahwa penyebab kematian ibu paling banyak diakibatkan masalah pendarahan dan keracunan kehamilan, sementara untuk kematian bayi dipicu beberapa masalah kesehatan, seperti berat badan di bawah 2,5 kilogram dan Asfiksia (ikilhojatim.com, 2021). Hal ini selaras dengan apa yang dikemukakan oleh Yuspa Hanum dan Tukiman bahwa resiko bagi gadis yang hamil saat usianya di bawah 20 tahun; 1). Menurut ilmu kedokteran, organ reproduksi perempuan usia di bawah 20 tahun belum siap berhubungan seks atau mengandung, jika terjadi kehamilan akan mengalami tekanan darah tinggi, yang nantinya akan menyebabkan kejang-kejang, pendarahan bahkan kematian pada ibu atau bayinya. 2). Sel telur perempuan di bawah usia 20 tahun belum begitu sempurna dan dikhawatirkan bayi mengalami cacat secara fisik. 3). Berisiko mengalami kanker serviks, karena semakin muda usia pertama kali orang melakukan hubungan seks, maka semakin besar risiko daerah reproduksi terkontaminasi virus (Hanum \& Tukiman, 2015).

\section{Tahap Evaluasi}

Kegiatan pendampingan ini merupakan salah satu program strategis yang dicanangkan oleh Universitas Nurul Jadid. Sebagaimana disampaikan oleh Rektor Universitas Nurul Jadid bahwa pendampingan harus berorientasi pada nilai kebermanfaatan kepada masyarakat. Keberadaan pendampingan ini diapresiasi oleh seluruh pengurus pesantren, karena dinilai sangat bermanfaat bagi santri di pondok pesantren Zainul Bahar. Namun beberapa hal yang perlu dievaluasi dalam kegiatan pendampingan ini adalah belum 
disiplinnya pelaksanaan pendampingan, utamanya dari pihak peserta dampingan. Hal ini wajar, karena pelaksanaan pendampingan yang diselenggarakan setiap hari jumat terkendala dengan hadirnya waktu sambang wali santri, sehingga menyebabkan beberapa peserta yang ijin dan/atau ikut di sebagian waktu. Selanjutnya, materi yang disampaikan dinilai oleh sebagian santri bias gender, hal ini disebabkan materi-materi yang disampaikan hanya lebih menekankan dan menitikberatkan pada kewajibankewajiban kaum perempuan (istri), sementara kewajiban suami minim diuraikan.

\section{Kesimpulan}

Berdasarkan paparan di atas, dapat disimpulkan bahwa untuk mewujudkan keluarga yang sakinah, maka seorang istri harus mengamalkan beberapa ajaran yang tertuang dalam kitab al-Mar'atu as-Sholehah antara lain 1). Mengkomunikasikan setiap persoalan yang muncul dengan suami, 2). Tidak boleh mencela setiap pemberian suami, 3). Tidak membandingbandingkan suaminya dengan orang lain, 4). Tidak bersikap boros dan/atau terlalu pelit, 5). Tidak berhutang kecuali dharurat, dan sebagainya.

\section{References}

BPS. (2018). Jumlah Pondok Pesantren dan Santri Kabupaten Bondowoso. Badan Pusat Statistik.

Djamilah, D., \& Kartikawati, R. (2014). Dampak Perkawinan Anak di Indonesia. Jurnal Studi Pemuda, 3(1). https://doi.org/10.22146/studipemudaugm.32033

Hakiki, G., \& dkk. (2020). Pencegahan Perkawinan Anak: Percepatan yang Tidak Bisa Ditunda. https://www.unicef.org/indonesia/media/2851/file/Child-MarriageReport-2020.pdf

Hamang, M. N., \& Sumadin. (2015). Pola Pembinaan Ketaatan Beragama Anak Di Panti Asuhan Abadi Aisyiyah Parepare. Istiqra, 2(2). http://jurnal.umpar.ac.id/index.php/istiqra/article/view/229 
Hanum, Y., \& Tukiman, T. (2015). DAMPAK PERNIKAHAN DINI TERHADAP KESEHATAN ALAT REPRODUKSI WANITA. Jurnal Keluarga Sehat Sejahtera, 13(2). https://doi.org/10.24114/jkss.v13i26.3596

ikilhojatim.com. (2021). Angka Kematian Ibu dan Anak di Bondowoso Meningkat. https://ikilhojatim.com/angka-kematian-ibu-dan-anak-dibondowoso-meningkat/

Inayati, I. N. (2015). Perkawinan Anak di Bawah Umur dalam Perspektif Hukum, HAM, dan Kesehatan. Jurnal Bidan: Midwife Journal, 1(1), 4653.

Marzuki, I. (2021). Seputar Kegiatan PP. Zainul Bahar [Personal communication].

Munadiroh, S. (2018). Konsep Pendidikan Akhlak Istri Terhadap Suami dalam Kitab Al-Mar'ah Ash-Sholihah Karya KH. Masruhan Al-Maghfuri [Institut Agama Islam Negeri (IAIN) Salatiga]. http://perpus.iainsalatiga.ac.id/lemari/fg/free/pdf/?file=http://perpus. iainsalatiga.ac.id/g/pdf/public/index.php/?pdf=4427/1/skripsi

Undang-Undang Nomor 1 Tahun 1974 Tentang Perkawinan, 1 Tahun1974 (1974). https://peraturan.bpk.go.id/Home/Details/47406/uu-no-1tahun-1974

Undang-undang (UU) tentang Perubahan atas Undang-undang Nomor 1

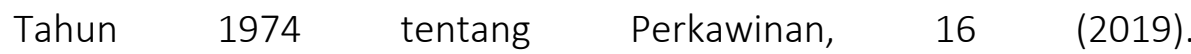
https://peraturan.bpk.go.id/Home/Details/122740/uu-no-16-tahun2019

Qibtiyah, M. (2014). Faktor yang Mempengaruhi Perkawinan Muda Perempuan. Jurnal Biometrika Dan Kependudukan, 3(1), 50-58.

Wafiq, A., \& Santoso, F. S. (2017). Upaya Yuridis Dan Sosiologis Kantor Urusan Agama Dalam Pencegahan Pernikahan Usia Dini. Ulumuddin: Jurnal IImu-IImu Keislaman, 7(1), 17-30. https://doi.org/10.47200/ulumuddin.v7i1.181

Wibisana, W. (2016). Pernikahan dalam Islam. Jurnal Pendidikan Agama Islam; Ta'lim, 14(2). https://d1wqtxts1xzle7.cloudfront.net/57103423/05_PERNIKAHAN_D ALAM_ISLAM_-_Wahyu-with-cover-page- 
v2. pdf? Expires $=1630567685 \&$ Signature $=M Y$ YluSqf3YHq8rS8rBXfBffsSJr I5ywctiCwaNaman8K8MffnM7Uumug3TwFluqVP5OdgZJjAV1MGFFxb AeMbPtUye02CqN viZAHvmTOoGduaHHrIM5NBI5bHoi7kOolgXgGOGU4h5ORFaLCcjqf N9JbKD iUXRjssrPsZfqHCRisktjyQLSurbg7RQu5pSM RwqEct43LjOnRg2fiQmLXSQVWhf58knsZVcOEmv06T2dFy2lj7zatwT5 Biu9Fnri srMWJ G2LQUudNvLy3tPGEeyqSKziSdd50QpCFYXJ4kpBTQv ng0xBrgw33bA9 LtKHIlykS5-N5Awj8xw_\&Key-PairId=APKAJLOHF5GGSLRBV4ZA 